Instructions for authors, subscriptions and further details:

\title{
http://mcs.hipatiapress.com
}

\section{The Dynamics of Masculinity in Contemporary Spanish Culture}

Ricardo Palmeiro Anastácio

1) Universidad de Deusto, Spain

Date of publication: February $21^{\text {th }}, 2018$

Edition period: June 2018-October 2018

To cite this article: Palmeiro Anastácio, R. (2018). The Dynamics of Masculinity in Contemporary Spanish Culture [Review of the book].

Masculinities and Social Change 7(1), 103-105. doi:

10.17583/MCS.2018.3275

To link this article: http://dx.doi.org/10.4471/MCS.2018.3275

PLEASE SCROLL DOWN FOR ARTICLE

The terms and conditions of use are related to the Open Journal System and to Creative Commons Attribution License (CC-BY). 
MCS - Masculinities and Social Change Vol. 7 No. 1 February 2018 pp. 103-105

\section{Reviews (I)}

Ryan, L., \& Corbalan, A. (Eds.). (2017). The Dynamics of Masculinity in Contemporary Spanish Culture. New York: Routledge. ISBN: 978-1-47248727-8

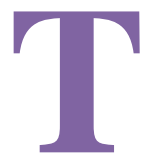

he socio-cultural transformations that changed Spain in the twentieth and twenty-first centuries led to a transmutation of masculinity, causing the birth of new types of masculine representation which in turn were later substituted by others. From the type of man of the Francoist era, who was expected to fulfill perfectly the patriarchal role, to the time of the transition in which he extolled the urban man of the city. In the 1980s, entrepreneurial masculinity, the discovery of capitalism and the welfare state were exalted, although social instruments were also developed that questioned the most harmful and offensive expressions of masculinity, in relation to macho behaviour, fatherchild relations, and relationships with other men in a professional or economic situation considered inferior.

This work is a collection of essays that explores and analyses the variations of masculine identities in Spain in the last century through the observation of cultural phenomena that have participated in shaping society. Among the questions that are placed at the beginning, as research questions: what does it mean to be a man in present-day Spain? How has masculinity evolved since Franco's dictatorship? What are the dynamics of masculinity in contemporary Spanish culture? How has hegemonic masculinity been disputed in cultural productions?

The answers are given throughout the sixteen trials divided into three blocks. The first one is dedicated to the decay of the archetype of the Francoist man, continuing with the reconstruction or the search for the new hegemony in the masculinity of the eighties and nineties, and ending with a

2018 Hipatia Press

ISSN: 2014-3605

DOI: $10.17583 / \mathrm{MCS} .2018 .3275$ 


\section{Palmeiro-Dynamics of Masculinities [Book Review]}

look at the specific and emerging masculinities of the Basque Country, Catalonia and Morocco.

In the first block Colmeiro, Mayock Bezhanova, DiGiovanni and Ryan analyse the representations of masculinity prototypes in cultural products during the Franco era, as well as their subsequent revision. The second block analyses the changes in Spanish society and in the male representations that began in the transition and culminated in the years of José Luis Rodríguez Zapatero's government and "citizen socialism", which approved the right to marriage between people of the same sex, legislated the right to sexual identity and ratified harsher punishments for gender-based violence. These legislative changes brought about changes in the forms of family relations that already marked a clear trend towards individualism, as well as the advent of homosexual fatherhood, which meant a dichotomy for the movement itself. Pérez addresses in his essay the question of whether the search for legal advances results in the assimilation of LGTB individuals and the normative society, thus weakening their potential vindication. Alicia Castillo Villanueva addresses the crisis of masculinity caused by the recession and the social changes it brought about, and relates it to the increase in male chauvinism and hidden gender violence. Victoria Ketz analyses,"ReinFORCEment of Masculinity through Violence", the relationship between gender identities and violence and proposes a new look at the process of constructing masculinity.

Nina Molinaro addresses the issue of national fantasies of masculinity, and failed masculinities, and Maria Van Liew addresses the discontent of Spanish youth due to the feeling of abandonment by political and economic strata. Paul Julian Smith analyses the existing homoeroticism in a television series whose target audience is female and young. The stereotypes are inverted, the male body being exposed, the male is presented in its most sensitive facet, ensuring sexual success.

In the last block María DiFrancesco explores the transformations of Arab masculinities in contact with the host territory, Catalonia in this case. The essays by Song, Martínez Expósito and Namaste analyse the specific forms of masculinity of Basque society, in this case, by reaffirming the traditional, or by affirming the gender identity identified with the permanent conflict with the Spanish State. 


\section{MCS - Masculinities and Social Change, 7(1) 105}

In short, this collection of essays invites us to reflect on the transformations of masculinity prototypes in contemporary Spain and at the same time sets a new direction in gender identity studies. a crisis financiera de los últimos años ha hecho replantear muchos análisis sobre el devenir del neoliberalismo en occidente. El libro que presentamos en esta review es un ejemplo de ello pero en este caso a través del estudio de las aspiraciones educativas de los varones. De este modo, el libro empieza planteando un objetivo claro e importante en este contexto: entender qué factores sociales, culturales y especiales han influenciando la construcción de la masculinidad.

Ricardo Palmeiro Anastácio, Universidad de Deusto. palmeiroricardo@gmail.com 